\title{
PENINGKATAN KUALITAS LAYANAN BIMBINGAN SKRIPSI
}

\author{
H. Arwansyah 1)* \\ 1) Fakultas Ekonomi, Universitas Negeri Medan \\ * Penulis korespondensi: arwan.ibnu12@gmail.com
}

\begin{abstract}
Salah satu misi dari program studi pendidikan ekonomi adalah melaksanakan penelitian dan pengembangan keilmuan yang mendukung pellaksanaan pendidikan dan pembellajaran agar mampu menghasilkan berbagai inovasi dalam biidang pendidikan dan ekonomi, sebagai salah sagu prodi yang ada di FE Uniimed, sudah menjadi kewajiabn untuk berperan dalam menghasilkan lulusan yang memiliki kualitas dan dapat diandalkan sebagai penggerak pembangunan. Penelitian ini dilakukan dengan tujuan untuk mendiskripsikan secara faktual dan akurat tentang bagaimanakah kualitas layanan penelitian mahasiswa yang dilakukan oleh prodi, bagaimanakah kualitas penelitian yang dilaksanakan oleh mahasiswa, bagaimanakah Kualitas pembimbingan dan penulisan skripsi, dan bagaimanakah publikasi ilmiah hasil penelitian mahasiswa. Berdasarkan hasil penelitian ditarik kesimpulan bahwa bahwa kualitas pelayanan prodi terhadap penelitian mahasiswa tergolong Puas dengan frekuensi 45,52\% dari 60 responden. Begitu juga dengan kualitas bimbingan dosen terhadap penelitian mahasiswa yang juga tergolong Puas dengan frekuensi 50\%. Sehingga berdampak positif terhadap kualitas penelitian mahasiswa yang tergolong baik pada frekuensi $58,33 \%$. Namun berbanding terbalik dengan publikasi ilmiah penelitian mahasiswa yang masih tergolong kurang baik lebih kurang 41,66\% karena disebabkan masih kurangnya pemahaman mahasiswa tentang cara menyusun jurnal dan mempublikasikan jurnal ilmiah.
\end{abstract}

Keyword: Skripsi, Layanan, Publikasi Ilmiah. 


\section{PENDAHULUAN}

Institusi pendidikan tinggi dapat dilihat sebagai institusi yang bergerak di sektor jasa. Sejalan dengan kecenderungan yang berlangsung di industri jasa, perhatian terhadap kualitas insitusi pendidikan tinggi juga semakin meningkat (O’Neill dan Palmer, 2014). Hal ini disebabkan karena, pada saat ini, institusi pendidikan tinggi dihadapkan pada semakin ketatnya persaingan dimana lulusan perguruan tinggi harus mampu bersaing dipasar kerja. Kemudian juga para lulusan SMA/K memiliki sangat banyak pilihan pendidikan tinggi yang dapat dapat dipertimbangkan untuk menjadi tempatnya dalam menuntut ilmu. Dalam hal ini, salah satu ukuran kinerja penting pada institusi pendidikan tinggi adalah kualitas layanan dan kepuasan yang dirasakan oleh mahasiswa/calon mahasiswa terkait dengan program dan layanan yang diberikan (Seaman dan O'Hara, 2016).

Ketatnya persaingan menuntut perlunya peningkatan kualitas pendidikan dalam semua aspek, termasuk penelitian mahasiswa sebagai bagian tugas yang harus dilaksanakan khususnya mahasiswa yang akan menyelesaikan studi, dengan menulis skripsi. Perguruan Tinggi harus menyadari bahwa layanan yang diberikan secara konsisten akan memunculkan suatu ukuran standar mengenai pelayanan yang baik pada suatu program studi. Sebaliknya, suatu pemberian layanan jasa yang tidak bermutu akan mengarah pada perubahan sikap umum dan memunculkan respon negatif.

Pelayanan jasa yang buruk dapat terjadi apabila terdapat ketidakkonsistenan antara kepercayaan yang seseorang anut tentang apa yang akan ia terima dengan tindakan sebenarnya ia terima (disonansi) dan apabila terdapat ketidakkonsistenan antara tampilan yang diharapkan dengan tampilan aktual (diskonfirmasi). Dengan kata lain, pemberian layanan jasa yang buruk yang mengarah pada disonansi dan diskonfirmasi dapat terjadi apabila pelayanan yang diberikan oleh suatu program studi tidak sesuai dengan apa yang diharapkan oleh mahasiswanya. Respon negatif yang muncul dari pelayanan yang buruk tersebut, antara lain timbulnya sejumlah besar pelanggan (dalam hal ini mahasiswa) yang memiliki pengalaman buruk dalam mengkonsumsi suatu jasa (disastifaksi) dan timbulnya sejumlah besar mahasiswa yang memiliki keyakinan bahwa jasa yang diberikan oleh program studi tersebut berkualitas rendah (disafeksi).
JURNAL NIAGAWAN Vol 6 No 2 Oktober 2017

Bila jumlah mahasiswa yang mengalami disastifaksi dan disafeksi tersebut cukup besar maka program studi tersebut menghadapi resiko kehilangan reputasi dan market share. Oleh karena itu pengelola program studi perlu melakukan pengelolaan atas ketidakkonsistenan yang terjadi (diskonfirmasi dan disonansi) secara efektif. Pengelolaan secara efektif akan menentukan apakah suatu insiden akan meluas menjadi penolakan umum atas suatu produk jasa atau tidak (Purwanto, 2000; Soekarno, 2008).

Sehubungan dengan kualitas layanan yang diterima oleh mahasiswa, hasil penelitian dari Badik (2016) mengindikasikan bahwa kualitas layanan yang buruk dapat mempengaruhi motivasi belajar seseorang. Menurut Kotler (2007), seseorang yang termotivasi akan siap untuk bertindak. Bagaimana orang itu bertindak akan dipengaruhi oleh persepsinya mengenai suatu situasi tertentu; hal ini berarti persepsi merupakan realitas bagi seseorang. Dua orang dalam kondisi motivasi yang sama dan memiliki tujuan situasi yang sama mungkin akan bertindak secara berbeda karena persepsi mereka terhadap suatu situasi berbeda. Persepsi adalah proses di mana individu memilih, merumuskan dan menafsirkan masukan informasi untuk menciptakan suatu gambaran yang berarti tentang suatu hal. Berdasarkan hal ini, persepsi terhadap kualitas layanan yang tidak sesuai dengan apa yang diharapkan oleh mahasiswa dikhawatirkan dapat mempengaruhi motivasi belajar mahasiswa yang bersangkutan.

Pelayanan akademik adalah tugas utama satuan kerja perguruan tinggi di tingkat fakultas, sebab keberhasilan layanan akademik sangat berpengaruh terhadap capaian kinerja sivitas akademika yang ada pada tingkat fakultas tersebut. Tentunya pelayanan akademik secara sistemik dilaksanakan oleh jurusan/program studi yang merupakan struktural organik pelaksana dan akan menjadi ujung tombak pelayanan tersebut. Menurut Dros (2008) Pelayanan akademik harus bersifat komprehensif khususnya menyangkut produk misalnya kurikulum dan rencana perkuliahan yang ditawarkan, proses (admisi, registrasi, belajar mengajar, student affair, jasa akademik dan non akademik) serta lingkungan (peka terhadap masalah kebutuhan stakeholder, sosial, etika, dan lingkungan hidup). Tidak kalah pentingnya adalah bahwa layanan akademik fakultas harus bisa memberikan kesamaan kesempatan 
(equality of opportunity) kepada setiap mahasiswa untuk mengembangkan diri sesuai dengan kemampuannya.

\section{TINJAUAN PUSTAKA Pengertian Manajemen Mutu}

Manajemen mutu merupakan strategi pengelolaan mutu yang berusaha memenuhi harapan pelanggan yang dilakukan secara bertahap dan terus menerus untuk mencapai peningkatan mutu. Suatu organisasi yang berhasil adalah organisasi yang tingkat efektivitas dan produktivitasnya semakin lama semakin baik. Kebermaknaan setiap organisasi akan dirasakan oleh para pelanggan, baik pelanggan internal maupun pelanggan eksternal dari organisasi. Gaspersz (2003 : 235) menyatakan bahwa ada beberapa dimensi yang harus diperhatikan untuk meningkatkan mutu layanan, yaitu:

1. ketepatan waktu pelayanan,

2. akurasi pelayanan,

3. kesopanan dan keramahan dalam memberikan pelayanan,

4. tanggung jawab, berkaitan dengan penerimaan pesanan dan penanganan keluhan dari pelanggan,

5. kelengkapan,

6. kemudahan mendapatkan pelayanan,

7. variasi model pelayanan, berkaitan dengan inovasi untuk memberikan pola -pola baru dalam pelayanan,

8. pelayanan pribadi, berkaitan dengan fleksibilitas, penanganan permintaan khusus, dan lain-lain,

9. kenyamanan dalam memperoleh pelayanan,

10. atribut pendukung pelayanan lainnya, seperti: lingkungan, kebersihan, ruang tunggu, fasilitas musik, AC, dan lainlain.

\section{Mutu Pelayanan Akademik}

Manajemen mutu layanan dalam pendidikan melewati beberapa proses sejak dari persiapan, perencanaan, dan pelaksanaan mutu jasa layanan pendidikan yang diharapkan para peserta didik. Konsep manajemen mutu layanan berarti mengutamakan layanan terhadap peserta didik dalam meningkatkan mutu, atau upaya perbaikan lembaga pendidikan secara komprehensif. Didalamnya tentu harus ada upaya dalam memperbaiki kultur lembaga pendidikan dan hal itu dimulai dari tindakan
JURNAL NIAGAWAN Vol 6 No 2 Oktober 2017 manajemen. Oleh karena itu , terdapat beberapa usaha yang dilakukan untuk mencapai kepuasan pelanggan pendidikan melalui perbaikan terus menerus, pembagian tanggung jawab dengan para pegawai, serta pengurangan pekerjaan tersisa dan pengerjaan ulang.

Menurut Moenir pelayanan public adalah kegiatan yang dilakukan seseorang atau sekelompok orang dengan landasan factor material melalui sistem, prosedur dan metode tertentu dalam rangka usaha memenuhi kepentingan orang lain sesuai dengan haknya (1995: 26). Miftah Toha memberikan definisi pelayanan publik adalah suatu usaha yang dilakukan seseorang atau sekelompok orang atau institusi tertentu untuk memberikan bantuan dan kemudahan masyarakat dalam rangka mencapai tuijuan tertentu. Pelayanan akademik adalah pelayanan yang berkaitan dengan kegiatan pendidikan di perguruan tinggi. Berdasarkan pengertian tersebut maka pelayanan akademik dapat diartikan sebagai usaha yang dilakukan oleh perguruan tinggi untuk memberikan kemudahan pada pemenuhan kebutuhan mahasiswa dalam hal yang berkaitan dengan kegiatan akademik.

\section{Konsep Dasar Sistem Manajemen Mutu ISO 9001:2008}

Pengertian mutu atau quality dapat ditinjau dari dua perspektif konsep. Pertama konsep mutu bersifat absolut atau mutlak, kedua konsep mutu bersifat relatif menurut Sallis (dalam Ali, 2009:334). Dalam konsep mutu absolut mutu merujuk pada sifat yang menggambarkan derajat baiknya suatu barang atau jasa yang diproduksi atau dipasok oleh suatu lembaga tertentu. Pada konsep mutu absolut derajat baiknya produk, barang atau jasa yang mencerminkan tingginya tigginya harga barang atau jasa itu, dan tingginya standar penilaian lembaga yang memproduksi atau pemasok terhadap barang itu. Sedangkan konsep mutu yang bersifat relatif, derajat mutu itu bergantung pada penilaian pelanggan. Keterlibatan pelanggan dalam menentukan suatu produk, baik barang maupun jasa adalah dengan cara produsen mempertimbangkan harapan dan kebutuhan pelanggan terhadap produk-produk yang dihasilkan, apakah memuaskan atau memenuhi kebutuhan mereka menurut Rinehart (dalam Ali, 2009:343). Peran penting pelanggan dalam menentukan mutu dengan menekankan bahwa sebuah mutu yang dirasa dari sebuah 
produk atau jasa adalah faktor utama yang mempengaruhi kesuksesan produk atau jasa tersebut menurut Petters (dalam Sallis, 2010:57).

ISO 9000 merupakan dokumen standar yang dapat diterapkan pada hampir keseluruhan kegiatan bisnis karena standar ISO-9000 dapat dipakai sebagai pedoman untuk desain manufakturing, penjualan, dan pelayanan untuk produk baik barang maupun jasa. Standar sistem mutu internasional seri ISO-9000 terdiri atas elemen-elemen berikut:(1) bagian pedoman (ISO-9001, ISO-9002, dan ISO- 9004,(2) bagian seri sertifikasi (ISO-9001, ISO-9002, dan ISO9003). ISO-9001 merupakan sistem mutu model untuk jaminan mutu dalam perencanaan, produksi, instalasi,dan layanan, ISO-9002 merupakan sistem mutu model untuk jaminan mutu dalam produksi, instalasi,dan layanan, dan ISO-9003 merupakan sistem mutu model untuk jaminan mutu dalam inspeksi akhir dan tes.

tandar ISO 9001 dapat diimplementasi oleh semua organisasi, perusahaan, lembaga baik yang menghasilkan produk maupun pelayanan jasa bahkan dapat diaplikasikan oleh organisasi seperti yayasan sosial yang sungguh- sungguh menginginkan sistem manajemennya baik. Sifat standarnya masih fleksibel yang implementasinya disesuaikan dengan kondisi keadaan organisasi.

Sistem manajemen mutu ISO 9001:2008 akan memberi maanfaat sebagai:

a. Sarana untuk menjamin tercapainya kepuasan pelanggan eksternal dan internal

b. Sarana untuk melaksanakan peraturan dan perunadang-undangan yang berlaku, secara konsisten

c. Saran untuk mencapai sasaran( objek) sekolah dan diintegrasikan dengan sistem manajemen ferfomance excellence education Criteria MBNQA, balance scorecard, leansix sigma-triz,dan computer based information system sebagai sarana untuk mencapai tujuan sekolah yang tertuang pada visi, misi serta nilai inti.

d. Saran untuk melaksanakan komunikasi organisasi, baik secara internal maupun eksternal secara konsisten.

e. Sarana untuk pengelolaan sumber daya (keuangan, manuasia, lingkungan, material, saran dan prasarana, energy, metode, informasi, serta pengukuran)

f. Sarana untuk pengelolaan lingkungan kerja serta lingkungan akademik
JURNAL NIAGAWAN Vol 6 No 2 Oktober 2017

g. Sarana untuk pengelolaan realisasi proses pembelajaran

h. Sarana untuk pengelolaan desain dan pengembangan kurikulum berbasis kompetensi

i. Sarana untuk pengelolaan proses pengadaan barang dan jasa

j. Sarana untuk perekrutan peserta didik, pendidik, dan tenaga kependidikan

k. Sarana untuk melakukan perbaikan berkesinambungan

1. Sarana untuk melakukan praktek baik pelaksanaan pendidikan

m. Sarana untuk memenuhi standar nasional pendidikan.

\section{METODE PENELITIAN}

Lokasi dan waktu Penelitian

Penelitian ini dilaksanakan di Prodi Pendidikan ekonomi Fakultas Ekonomi Unimed pada satuan kerja tingkat program studi. Waktu penelitian ini direncanakan selama 3 (tiga) bulan dimulai pada bulan Agustus s/d Oktober 2017.

\section{Populasi dan Sampel}

Untuk melihat kualitas layanan akademik mahasiswa maka yang menjadi Populasi dalam penelitian ini adalah seluruh Mahasiswa Prodi Pendidikan ekonomi Fakultas Ekonomi Unimed, Penelitian ini menggunakan teknik kemudahan (Convience sampling), yaitu dengan membagi sama jumlah sampel mahasiswa dari setiap Angkatan mulai tahun 2013 s/d 2015 yang ada.

\section{Jenis dan sumber data}

Jenis data penelitian ini adalah data primer dan data sekunder. Data primer berasal dari kuesioner yang diberikan kepada para responden yaitu mahasiswa Prodi Pendidikan ekonomi FE-Unimed sebagaimana yang tertera pada tabel 3.1. tersebut diatas. Kemudian data sekunder adalah data-data pendukung yang tersedia dan berkenaan dengan masalah penelitian dikumpulkan dengan teknik dokumentasi dari berbagai dokumen yang tersedia di FE Unimed sebagai referensi/rujukan.

\section{Tekhnik Pengumpulan data dan instrumen penelitian}

Teknik pengumpulan data yang digunakan adalah menggunakan :

1. Kuesioner/instrumen penelitian

2. wawancara, 


\section{Dokumentasi}

Instrumen penelitian diberikan kepada mahasiswa yang telah dipilih dan ditentukan sebelumnya berdasarkan teknik sampling untuk diminta mengisi kuesioner. Wawancara digunakan untuk melakukan pengecekan (crosscheck) terhadap berbagai sumber yang relevan, yaitu dosen, laboran, tenaga administrative penunjang kegiatan akademik.

\section{HASIL DAN PEMBAHASAN}

\section{Kualitas Layanan Prodi}

Banyak aspek yang menjadi pertimbangan seorang pimpinan untuk meningkaatkan layanan kepada seluruh stake holder termasuk kepada mahasiswa sehubungan dengan penulisan tugas akhir yang merupakan salah satu persyaratan bagi mahgasiswa untuk memmperoleh gelar kesarjanaannya. Terdapat beberapa pertimbangan yang menjadi tolok ukur tingkat kepuasan mahasiswa terhadap pelayanan prodi. Kualitas pelayanan atau customer service ini dapat dibedakan ke dalam empat kriteria yaitu sangat puas, puas tidak puas dan santa tidak puas. Kualitas pelayanan ini bukanlah suatu hal yang permanen atau kaku, melainkan fleksibel dan dapat dirubah. Perubahan ini tentunya berupa peningkatan kualitas pelayanan agar semakin lebih baik lagi. Dalam proses perubahan kualitas pelayanan tersebut diperlukan beberapa hal untuk menunjang prosesnya. Misalnya survei atau observasi kepada stake holder maupun mahasiswa, termasuk didalamnya berupa masukan, pendapat maupun feedback tentang pelayanan yang telah diberikan.

Kualitas pelayanan ini dapat diartikan sebagai tingkat kepuasan stake holder maupun mahasiswa. Sedangkan tingkat kepuasan mahasiswa ini sendiri dapat diperoleh dari perbandingan atas jenis pelayanan yang nyata diterima oleh mahasiswa dengan jenis pelayanan yang diharapkan oleh mereka. Jenis kualitas pelayanan yang baik adalah jenis pelayanan yang memuaskan dan sesuai dengan pelayanan yang diharapkan oleh para mahasiswa. Bila mana pelayanan ini dapat melampaui harapan mereka, maka jenis kualitas pelayanan ini dapat dikategorikan sebagai pelayanan yang sangat berkualitas atau sangat memuaskan. Sedangkan jenis kualitas pelayanan yang buruk atau tidak memuaskan adalah jenis pelayanan
JURNAL NIAGAWAN Vol 6 No 2 Oktober 2017 yang berada jauh di bawah standar atau tidak sesuai dengan ekspekstasi pelayanan yang diharapkan oleh mahasiswa.

Kualitas pelayanan ini menjadi penting karena akan berdampak langsung pada citra prodi. Kualitas pelayanan yang baik akan menjadi sebuah kebangga bagi poengelola prodi. Bagaimana tidak, jika prodi sudah mendapat nilai positif di mata mahasiswa, maka mereka akan memberikan feedback yang baik, serta bukan tidak mungkin akan menjadi salah satu indikator keberhasilan prodi bila dikasitkan dengan akreditasinya. Maka dari itu, sangat penting untuk mempertimbangkan aspek kepuasan mahasiswa terkait kualitas pelayanan yang diberikan. Jenis-jenis pelayanan yang dapat diberikan misalnya berupa kemudahan, kecepatan, kemampuan, dan keramahtamahan yang ditunjukkan melalui sikap dan tindakan langsung kepada para mahasiswa secara umumm, kkhususnya dalam penulisan karya ilmiah mahasiswa.

Berdasarkan Gambar 1 dibawah diperoleh, rata-rata $($ mean $)=106,87$, median $=$ 108 , modus $=104 ;$ std.deviasi $=14,09$. Berikut tabel distibusi terkait kualitas pelayanan prodi terhadap penelitian mahasiswa.

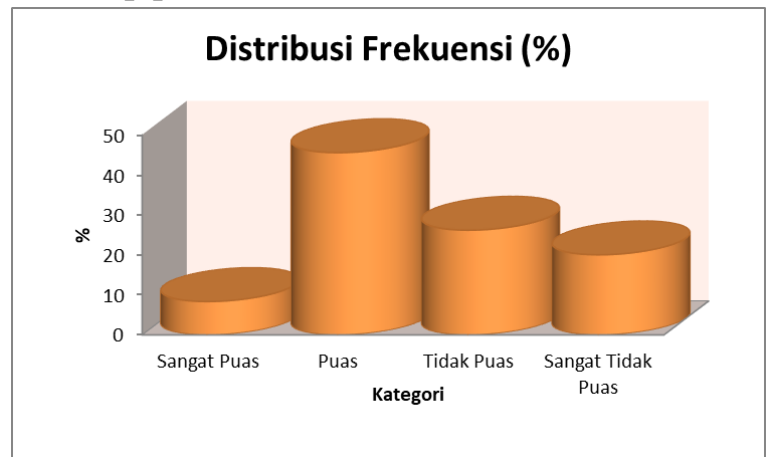

Gambar 1 Grafik Distribusi Frekuensi Kualitas Pelayanan Prodi

Berdasarkan Diagramm penelitian dari 60 responden diketahui analisis kualitas pelayanan prodi terhadap penelitian mahasiswa Pendidikan Ekonomi Universitas Negeri Medan mempunyai sikap puas yaitu sebesar $45,52 \%$, sikap tidak puas $26,15 \%$, sangat tidak puas $20 \%$, dan sangat puas sebesar $8,33 \%$. Berdasarkan hasil tersebut menerangkan bahwa kualitas pelayanan prodi terhadap penelitian mahasiswa adalah bersikap Puas. Hasil penelitian tersebut dipengaruhi oleh beberapa faktor, adapapun faktor yang mempengaruhinya adalah sebagai berikut: 
Bukti Langsung (Fasilitas, perlengkapan, sarana dan informasi)

Hasil perhitungan data diperoleh ratarata $($ mean $)=38,41$, median $=39$, modus sebesar $=40$, stamdard deviasi $=4,86$. Diketahui bahwa analisis kualitas pelayanan prodi terhadap penelitian mahasiswa dari faktor bukti langsung sebagian besar mempunyai sikap Puas sebesar $41,66 \%$, sikap tidak puas sebesar $25 \%$, sangat tidak puas sebesar $16,66 \%$, dan sangat puas sebesar $15,38 \%$

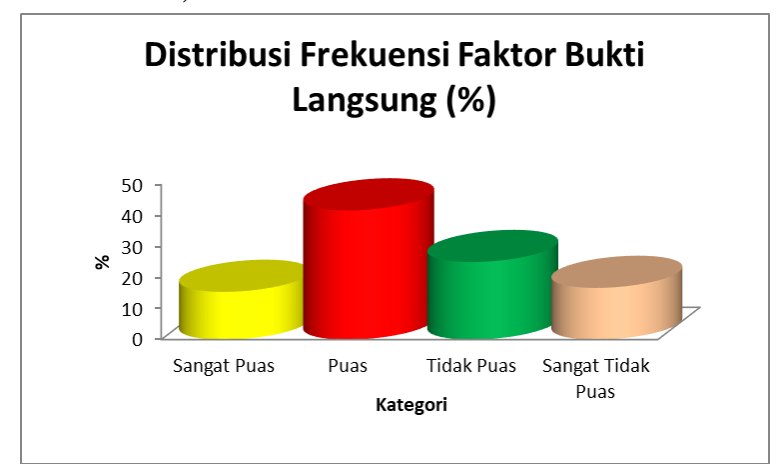

\section{Gambar 2. Grafik Distribusi Frekuensi Faktor Bukti Langsung}

Keandalan (Penyampaian jasa yang tepat, kesesuaian tindak lanjut)

Hasil perhitungan data dari faktor keandalan diperoleh rata-rata (mean) = 24,23, median $=24$, modus sebesar $=22$, standard deviasi $=3,53$.

\section{Distribusi Frekuensi Faktor Keandalan}

(\%)

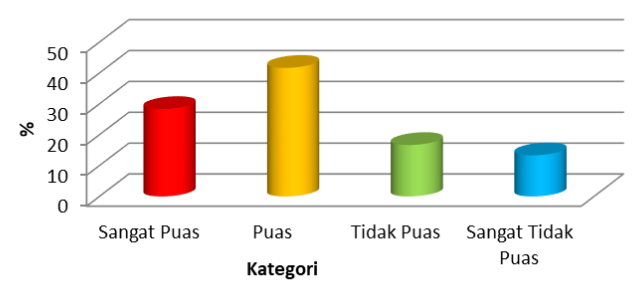

Gambar 3. Grafik Distribusi Frekuensi Faktor Keandalan

Berdasarkan gambar penelitian diatas, diketahui analisis kualitas pelayanan prodi terhadap penelitian mahasiswa dari faktor keandalan sebagian besar mempunyai sikap Puas sebesar $41,67 \%$, sikap tidak puas sebesar $16,67 \%$, sangat tidak puas sebesar $13,33 \%$, dan sangat puas sebesar $28,33 \%$.

Daya Tangkap (Respon pegawai, dan keluangan waktu )

Hasil perhitungan data dari faktor keandalan diperoleh rata-rata $($ mean $)=17,49$, median $=18$, modus sebesar $=15$, standard
JURNAL NIAGAWAN Vol 6 No 2 Oktober 2017 deviasi $=2,62$. Diketahui analisis kualitas pelayanan prodi terhadap penelitian mahasiswa dari faktor daya tangkap sebagian besar mempunyai sikap Puas sebesar 50\%, sikap tidak puas sebesar $25 \%$, sangat tidak puas sebesar $6,67 \%$, dan sangat puas sebesar $18,33 \%$.

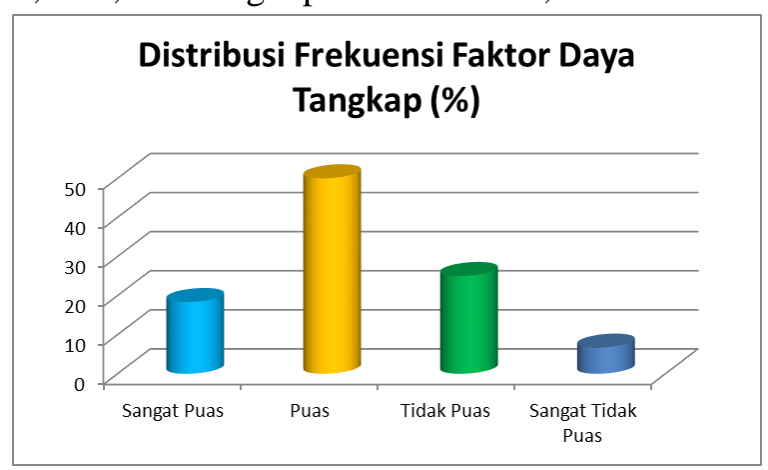

Gambar 4 Diagram Distribusi Frekuensi Faktor Daya Tangkap

Diketahui analisis kualitas pelayanan prodi terhadap penelitian mahasiswa dari faktor daya tangkap sebagian besar mempunyai sikap Puas sebesar 50\%, sikap tidak puas sebesar 25\%, sangat tidak puas sebesar $6,67 \%$, dan sangat puas sebesar $18,33 \%$.

Empati (perhatian prodi, memahami kebutuhan mahasiswa, kemudahan dalam melakukan hubungan)

Berdasarkan gambar 5, diketahui analisis kualitas pelayanan prodi terhadap penelitian mahasiswa dari faktor empati sebagian besar mempunyai sikap Puas sebesar $36,67 \%$, sikap tidak puas sebesar $31,67 \%$, sangat tidak puas sebesar $10 \%$, dan sangat puas sebesar $21,67 \%$.

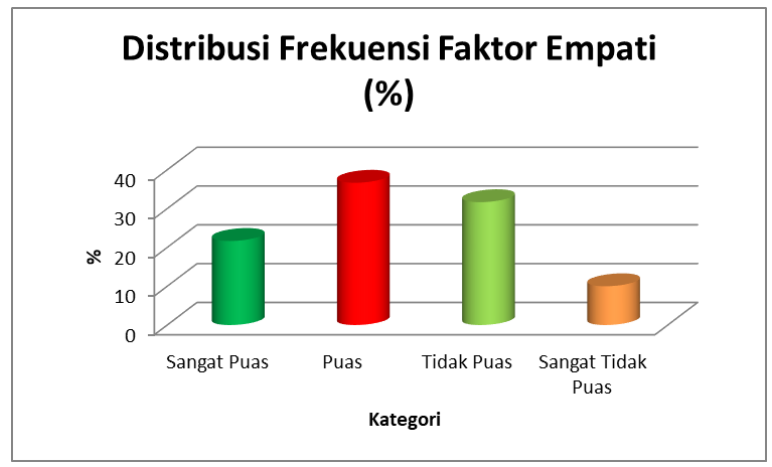

Gambar 5. Diagram Distribusi Frekuensi Faktor Empati

\section{Kualitas Penelitian Mahasiswa}

Berdasarkan Gambar 6 diperoleh, bahawa kualitas penelitian mahasiswa sebanyak $16,66 \%$ sangat baik dan sebanyaak 58,33\% berada pada katagori baik. 


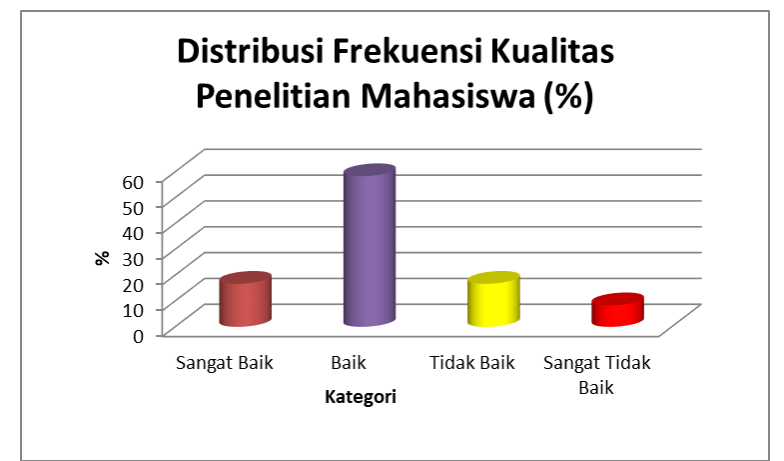

Gambar 6. Grafik Distribusi Frekuensi Kualitas Penelitian Mahasiswa

Berdasarkan hasil perhitungan statistik dari 60 responden diketahui analisis kualitas penelitian mahasiswa Pendidikan Ekonomi Universitas Negeri Medan mempunyai sikap baik yaitu sebesar $58,33 \%$, kategori tidak baik $16,66 \%$, sangat tidak baik $8,33 \%$, dan sangat baik sebesar $16,66 \%$. Berdasarkan hasil tersebut menerangkan bahwa kualitas penelitian mahasiswa program studi pendidikan ekonomi universitas negeri medan adalah berada pada katagori baik

\section{Kualitas Bimbingan Dosen}

Kualitas Bimbingan Dosen Pendidikan Ekonomi Universitas Negeri Medan mempunyai sikap baik yaitu sebesar $50 \%$, kategori tidak baik $16,66 \%$, sangat tidak baik $8,33 \%$, dan sangat baik sebesar 25\%. Berdasarkan hasil tersebut menerangkan bahwa kualitas bimbinngan dosen padda katagori baik.

\section{Publikasi Ilmiah Penelitian Mahasiswa}

Berdasarkan hasil perhitungan publikasi ilmiaah penelitian mahasiswa dari 60 responnden di peroleh, rata-rata (mean) $=35,95$, median $=56$, modus $=55$; std.deviasi $=19,19$.

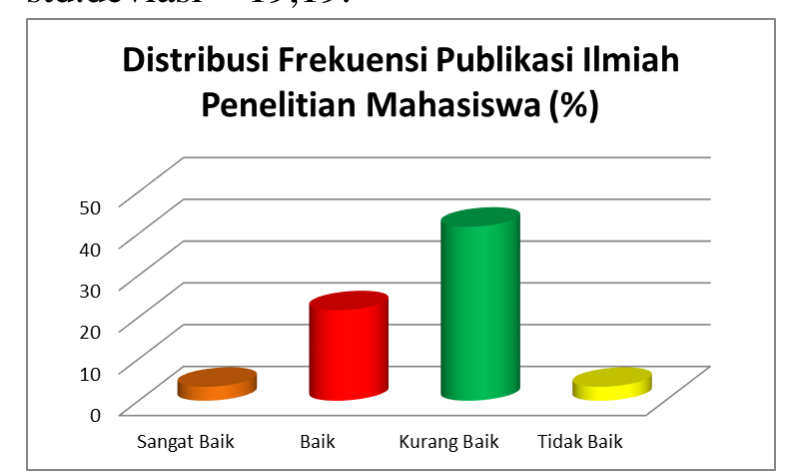

Gambar 7 Diagram Distribusi Frekuensi Publikasi Ilmiah Penelitian Mahasiswa

Berdasarkan gambar 7 di atas, dari 60 responden diketahui analisis publikasi ilmiah
JURNAL NIAGAWAN Vol 6 No 2 Oktober 2017 mahasiswa Pendidikan Ekonomi Universitas Negeri Medan mempunyai sikap baik yaitu sebesar 21,66\%, kategori kurang baik 41,66\%, tidak baik $33,33 \%$, dan sangat baik sebesar $3,33 \%$. Berdasarkan hasil tersebut menerangkan bahwa publikasi ilmiah penelitian mahasiswa program studi pendidikan ekonomi universitas negeri medan adalah kurang baik. Hal itu disebabkan masih banyaknya mahasiswa tidak memahami cara pembuatan jurnal dan lain sebagainya

\section{SIMPULAN DAN SARAN}

\section{Simpulan}

Berdasarkan pembahasan diatas dapat disimpulkan bahwa kualitas pelayanan prodi terhadap penelitian mahasiswa tergolong Puas dengan frekuensi $45,52 \%$ dari 60 responden. Begitu juga dengan kualitas bimbingan dosen terhadap penelitian mahasiswa yang juga tergolong Puas dengan frekuensi 50\%. Sehingga berdampak positif terhadap kualitas penelitian mahasiswa yang tergolong baik pada frekuensi $58,33 \%$. Namun berbanding terbalik dengan publikasi ilmiah penelitian mahasiswa yang masih tergolong kurang baik lebih kurang 41,66\% karena disebabkan masih kurangnya pemahaman mahasiswa tentang cara menyusun jurnal dan mempublikasikan jurnal ilmiah.

\section{Saran}

Berdasarkan hasil penelitian ini dapat disampaikan beberapa saran sebagai berikut:

1. Kualitas Pelayanan Prodi terhadap penelitian mahasiswa agar tetap dipertahankan dan harus dapat di tingkatkan kembali.

2. Lebih diperhatikan kembali publikasi ilmiah mahasiswa agar dapat meningkatkan kualitas programstudi dalam penelitan mahasiswa.

\section{REFERENSI}

Badudu, J.S. dan Sutan Muhammad Zain. (2001). Kamus Umum Bahasa Indonesia. Jakarta: PT Intergrafika.

Berman B., 1990, Marketing. Macmillan Publising Company, New York.

Gaspersz, Vincent, 2003, Total Quality Management. Gramedia Pustaka Utama, Jakarta. 
Fandy Tjiptono. (2003). Manajemen Jasa. Yogyakarta: Andi Offset.

Hopson, Barrie. (1997). 12 Langkah Menuju Pelayanan Bermutu (terjemahan Purborini Sulistya). Jakarta: Arcan.

Ghozali, Imam dan Fuad., (2015), Structural Equation Modeling, Teori Konsep dan aplikasi. Badan Penerbit Universitas Diponegoro, Semarang .

Lawrence A. Sherr, G. Gregory Lozier, 2005, Total Quality Management in Higher Education. Diambil pada tanggal 16 Agustus 2005 dari

Marc R. Testa, 1999, Satisfaction with Organizational Vision, Job Satisfaction, and Service Efforts: An Empirical Investigation. Leadership \& Organization Development Journal. MCB. University Press.

Mastuhu. 2004. Menata Ulang Pemikiran Sistem Pendidikan Nasional dalam Abad 21. Yogyakarta: Safiria Insania Press.

Miftah Thoha. (1991). Beberapa Aspek Kebijakan Birokrasi. Yogyakarta: Media Widya Mandala.

Moenir, A.S. (1995). Manajemen Pelayanan Umum di Indonesia. Jakarta: Bumi Aksara.

Payne, Adrian, 2000, Service Marketing, Andi, Yogyakarta.

Rivai Hutapea. 2003. "bongkar Total Pendidikan Kita”. Sabili, 31 Juli 2003.

Sallis, Edwaar, 1993, Total Quality Management in Education. Kogan Page Limited, London.

Sudarwan Danim. 2003. Agenda pembaruan Sistem Pendidikan. Yogyakarta: Pustaka Pelajar.

Sugiarto. (1999). Psikologi Pelayanan dalam Industri Jasa. Jakarta: PT Gramedia.
JURNAL NIAGAWAN Vol 6 No 2 Oktober 2017 Tampubolon. (2001). Manajemen Pendidikan. Jakarta

Tjiptono, Fandy dan Diana, 2003, Total Quality Management. Penerbit Andi, Yogyakarta.

Tjiptono, Fandi, 2004, Manajemen Jasa. Penerbit Andi, Yogyakarta.

Tjiptono, Fandi dan Gregorius, 2005, Service Quality Satisfaction. Penerbit Andi, Yogyakarta.

http://campus.umr.edu/assess/tqm/tqmhed.html. 